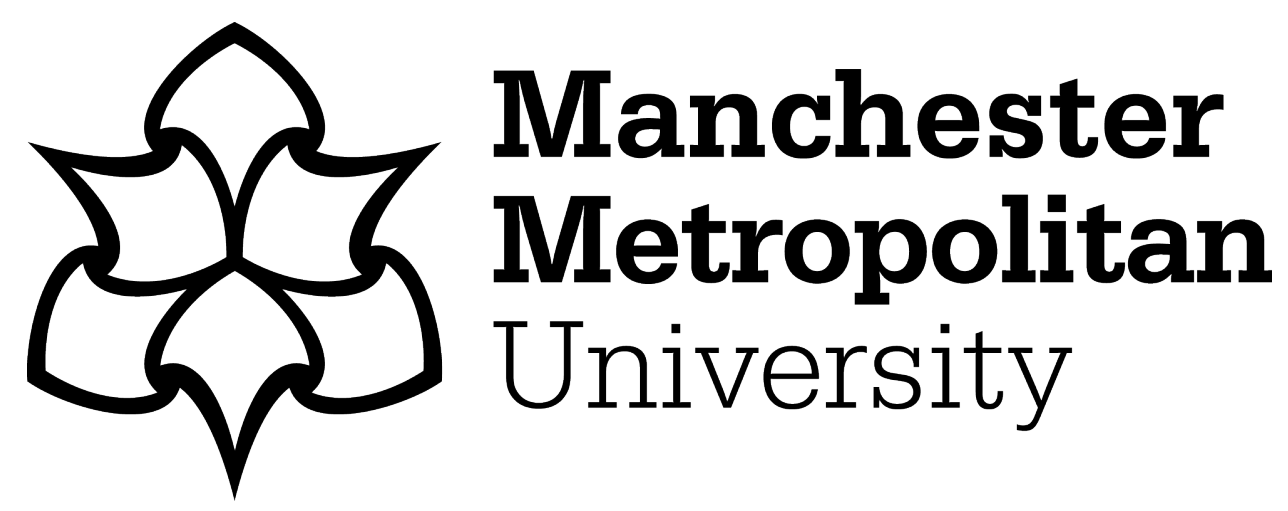

Pacheco Junior, MA, Anholon, R, Rampasso, IS and Leal Filho, W (2021) Improving research labs' performance through project management guidelines: a case study analysis. International Journal of Productivity and Performance Management, 70 (3). pp. 704-721. ISSN 1741-0401

Downloaded from: https://e-space.mmu.ac.uk/626518/

Version: Accepted Version

Publisher: Emerald

DOI: https://doi.org/10.1108/IJPPM-11-2019-0536

Please cite the published version 


\title{
Improving research labs performance through project management guidelines: a case study analysis
}

\author{
Manual Pacheco Junior MA, Anholon R, Rampasso IS, Leal Filho W \\ International Journal of Productivity and Performance Management 01 Jan 2020 DOI \\ https://www.emerald.com/insight/content/doi/10.1108/IJPPM-11-2019-0536/full/html
}

\begin{abstract}
Purpose: The article aims to critically analyze the project management developed by research laboratories of a Brazilian university in order to enhance their performance. For this, a critical analysis was performed to identify existing opportunities about the management of schedules and resources. Additionally, a software was developed to enable performance improvement.
\end{abstract}

Design/methodology/approach: The methodological procedures used were literature review, for a theoretical foundation, and case study conducted with semi-structured interviews, documentary research, and on-site visits. Through a detailed critical analysis of the laboratories' management, it was possible to understand the activities developed and map the main difficulties observed.

Findings: Five plausible points of improvement were identified, namely: reduced teams and accumulation of activities; team seasonality; centralized management; deviations from projects; schedule control. Based on the theoretical foundation, it has been proposed adjustments to minimize the mentioned difficulties that can greatly contribute to better management efficiency of multiple research projects. In addition, a software was structured based on the proposed improvements. The laboratories' performance were monitored for a month and significant improvements were observed.

Practical implications: The information presented here may be of great value to other researchers interested in enhancing of research laboratory performance.

Originality/value: The academic literature presents several examples of project management guidelines application in different organizations, however, there are few studies about the application of them in research laboratories and how to improve their performance.

Keywords: Performance; Research laboratories; Project management; Schedule management; Resources management. 


\section{Introduction}

In the international context, innovation is considered a fundamental aspect for the competitiveness of organizations (Zhu and Cheung 2017; Le and Lei 2018; Salehi et al. 2018; Ndubisi et al. 2019). Managing innovation processes efficiently and establishing alliances and partnerships is characterized as the first step towards market conquest and longevity of companies (Anthony et al. 2016; Ortiz-Villajos and Sotoca 2018; Mazzucchelli et al. 2019).

In this context, the triple helix model stands out, emphasizing the need of interaction among universities, companies and the government. According to Etzkowitz and Zhou (2017), the university participates as a source of entrepreneurship, technology and innovation, as well as research, critical analysis, education and preservation of cultural heritage; Government is committed to providing resources, funding research and stimulating organizational entrepreneurship as an incentive to create new businesses.

In the university environment, research centers can be highlighted. They are characterized as important mechanisms for science advancement, since they may enhance research results when compared to traditional groups formed solely by a professor and his/her students (Boardman and Gray 2010). For Gray (2008) and Boardman and Gray (Boardman and Gray 2010) these centers enable the management of large research projects, characterized by multidisciplinarity and complexity. Authors such as Boardman and Bozeman (2007), Gray (2010) and Nishimura et al. (2018) corroborate with this viewpoint. There are many existing research centers in the world and, in general, they are linked to major universities (Grad School Hub 2018).

In their broad conception, research centers aim to generate innovations through scientific development, and, in most cases, several projects are developed simultaneously (Lind et al. 2013; Dalmarco et al. 2015). On average, these projects last a predetermined period and compete for financial and human resources with other existing projects. The results from these projects are characterized by new knowledge disclosed in the form of scientific articles and patents (ANP 2016).

When analyzing the situation described in the previous paragraph, it is observed that the management of a research laboratory, in terms of projects, is similar to the reality of a company and, through this, guidelines for organizational projects management can be used to boost search results.

The University of Campinas (Unicamp) have several research centers and, among them, Petroleum Research Center (CEPETRO) stands out. This center is composed by several 
research groups, among them the Artificial Lift \& Flow Assurance Research Group (ALFA Research Group), which coordinate the activities at LABPETRO (Experimental Petroleum Laboratory "Kelsen Valente") and the LGE (Laboratory of Flow Assurance) linked to the School of Mechanical Engineering. These laboratories develop research projects simultaneously and, therefore, need to optimize their resources management, including people and equipment. They are characterized as multiproject environments. As in most companies, resources cannot be dedicated to a single project and must be shared. In addition, managing schedules and other aspects is also essential to meet deadlines (Cunha and Moura 2011).

Based on the context presented above, this article aims to perform a critical analysis of project management developed in the previously mentioned laboratories, aiming to identify opportunities for performance improvement in the light of the literature. Based on the identified opportunities, a software will be structured to better manage resources and schedules.

In addition to this introduction, this article is composed of four more sections. Section 2 is intended for theoretical background, with emphasis on aspects of project schedule and resource management. Section 3 is intended to present the methodological procedures. Section 4 is devoted to the presentation of results and discussions, and finally section 5 to the conclusions.

\section{Theoretical background}

Project management is a discipline that combine concepts from diverse areas, providing organizations with the means to be effective and competitive in unpredictable, complex and ever-changing environments (Ika 2009). There are several authors that related project management with performance improvements (Cullen and Parker 2015; Larsson et al. 2018; Jugdev et al. 2019). The manner projects can be managed is a major challenge and the multiple plausible forms of management are studied by the Project Management discipline. Project management is an increasingly indispensable competence for organizations (Marques Junior and Plonski 2011; Patah and Carvalho 2016; Tereso et al. 2019).

Executing projects effectively and efficiently in non-homogeneous environments induces the search for environment peculiarities, motivations and differences that are shaped by movements of the project management theme. Currently, the most executed movements, explored and worked in organizations and relevant in the literature are two: the traditional and the agile (Fernandez and Fernandez 2008; Edison 2015; Serrador and Pinto 2015). 
The line called "traditional" is the oldest one and it is prior to the emergence of new theories. Although first practices, tools and techniques were developed in 1950, this line is very lively, current and realistic, consisting of project management guides that provide generic guidelines for managing any type of project, regardless of size and complexity (Almeida et al. 2012; Eder et al. 2012; Eder et al. 2015).

On the other hand, the "agile" movement is an emerging approach that proposes principles, actions, techniques and tools called as new, in an area called Agile Project Management (APM), which has been evolving since the creation of "Manifesto for Agile Software Development" (Beck et al. 2001; Serrador and Pinto 2015; Azanha et al. 2017; PMI 2017). The Manifesto was written by a group of professionals who proposed methods, practices and tools to improve project performance, promoting agility and breaking paradigms of the traditional project strand (Serrador and Pinto 2015; Conforto et al. 2016)

According to Eder et al. (2015), both movements, traditional and agile, differ mainly by the techniques used. The planning and control actions are similar, thus, the fundamental differences between the approaches are in the form of execution, characterized by the techniques.

In addition to these two movements, there are other movements in the literature, such as Rethinking Project Management, and Hybrid Project Management. The Rethink in Project Management (RPM) movement, between 2005 and 2012, aimed to rethink projects and their forms of management in view of the challenges existing at the time and several existing project management failures. The movement presented a classical approach characterized with the following characteristics: executability, simplicity, temporality, linearity, controllability and instrumentality (Cicmil et al. 2006; Winter et al. 2006; Zwikael 2016).

Hybrid Project Management is an evolving movement that began in 2015. This line of thinking has the prerogative of obtaining tools and practices consolidated on other fronts and aggregating them, adapting them to a new model. However, it is emphasized that adaptability is possible as long as the principles and concepts of the tool or practice used are respected (Conforto and Amaral 2015; Gledson 2016; Hoda et al. 2017). There are some authors, such as Baird and Riggins (2012), Conforto and Amaral (2015) and Sarkar and Locatelli (2018), purposed models and frameworks in this line of reasoning that, generally, select practices and tools from the traditional and agile line. The movement generates development benefits to the field, providing a different perspective to the mentioned lines.

Focusing on the actions developed in project management, activities associated to schedule and resources management should be highlighted (Berssaneti and Carvalho 2015; Hu 
et al. 2016; Vargas 2016). The traditional line of project management has an area called "schedule management". It provides a plan that represents how and when the project will deliver products, services and results. Six processes are recommended in a schedule management: planning; activities definition; activities sequencing; duration of activities; schedule development; schedule control. Regarding the tools to be used, it may be highlighted graphics, mathematical analysis, data analysis and compression (PMI 2017).

Charts are an easy, structured manner to view activities, dates, and milestones. Although there are others such as the project schedule network diagram, the most commonly used is the Gantt chart. Proposed by Henry Gantt, this chart is a useful and easy tool for presenting time information about plans and allows the project manager to track activities (Darmody 2007).

Mathematical analysis aims to calculate theoretical start and end dates for all activities. The results indicate the time periods in which the activities should be started, respecting resource limitations and other restrictions. Some of the tools commonly used by companies for this purpose are: Critical Path Method (CPM), Program Evaluation and Review Technique (PERT), Critical Chain Project Management (CCPM) and Graphical Evaluation and Review Technique (GERT) (Cooper Ordoñez 2013; PMI 2017).

In the agile management line, there is a paradigm shift, because there is no schedule management, but the concept of predefined deadline or Timeboxed, coupled with the concept of continuous deliveries, conducted through iterations (Davidson and Klemme 2016; P.M.I. PMI 2017).

Defined deadlines are events that happen during the methodology execution, with defined deadlines that favor and provide agility. These deadlines are: Sprint, Sprint Planning Meeting, Daily Meeting, Sprint Review and Sprint Retrospective. Sprint is defined as the time of an iteration, which can last from two weeks to one month, with the expectation of a product delivery at the end. The Planning Meeting occurs when the team conducts task estimation activities and equates only what fits during the Sprint period. The most flexible form allows a management not focused on the entire project, but focused on reduced planning and on what is required to deliver on the iteration (Conforto et al. 2016; P.M.I. PMI 2017). As the agile line values transparency and team interaction, in daily meetings, delays and problems are pointed out by the teams, which enables a monitoring of Sprint's deadline (SCRUMstudy 2016).

In the traditional line of projects, resource management is comprehensive and can be viewed from several angles, i.e. environmental factors, team building, and team availability. Regarding the environmental factors of an organization, it is considered the geographical distribution of facilities and resources, virtual teams, shared systems and even the retention or 
sharing of knowledge produced, for the team itself and other teams (Park and Lee 2014; Kerzner 2016; PMI 2017). In team building, there is a need to determine the skill levels required to carry out the project activities, which competencies, expertise and skills are required, as well as a project manager (PMI 2017; Turner et al. 2018). In the availability of resources, the availability of human resources and equipment, as well as their overload are analyzed (Zika-Viktorsson et al. 2006; PMI 2017).

On staff availability, there are several researches focused on solving dedicated resource issues such as Resource Dedication Problem (RPD) or Resource-Constrained Project Scheduling Problem (RCPSP). In general, theories are based on the fact that each activity in the project requires one or more resources, that can be renewable (available after the task) or nonrenewable (with prioritized tasks scheduled) (Hendriks et al. 1999; Beşikci et al. 2013; Beşikci et al. 2015; Habibi et al. 2018).

In the agile line of projects, the term resource management is not explicit, especially when the focus is on promoting collaboration to boost productivity and team performance. This line prioritizes the formation of multidisciplinary teams to avoid the dependency of external resources to perform tasks, since the necessary knowledge to develop a delivery is contained in the team (Conforto et al. 2016; P.M.I. PMI 2017).

\section{Methodological procedures}

This section aims to present the steps conducted in this research. According to Yin (2014), a case study can be used to analyze specific cases useful for academic community. In this study, an uncommon project management of research laboratories is presented, which can be useful for other laboratories in Brazil and other countries. For this, a case study based on interviews was performed in two research laboratory of petroleum engineering field. Since the two analyzed laboratories belong to the same research group (ALFA Research Group) and present several similarities with each other, we consider this research as a single case study. Six steps were defined to ensure the reliability and replicability of the methodological procedures used. Figure 1 presents these steps and, in the sequence, they are debated. 


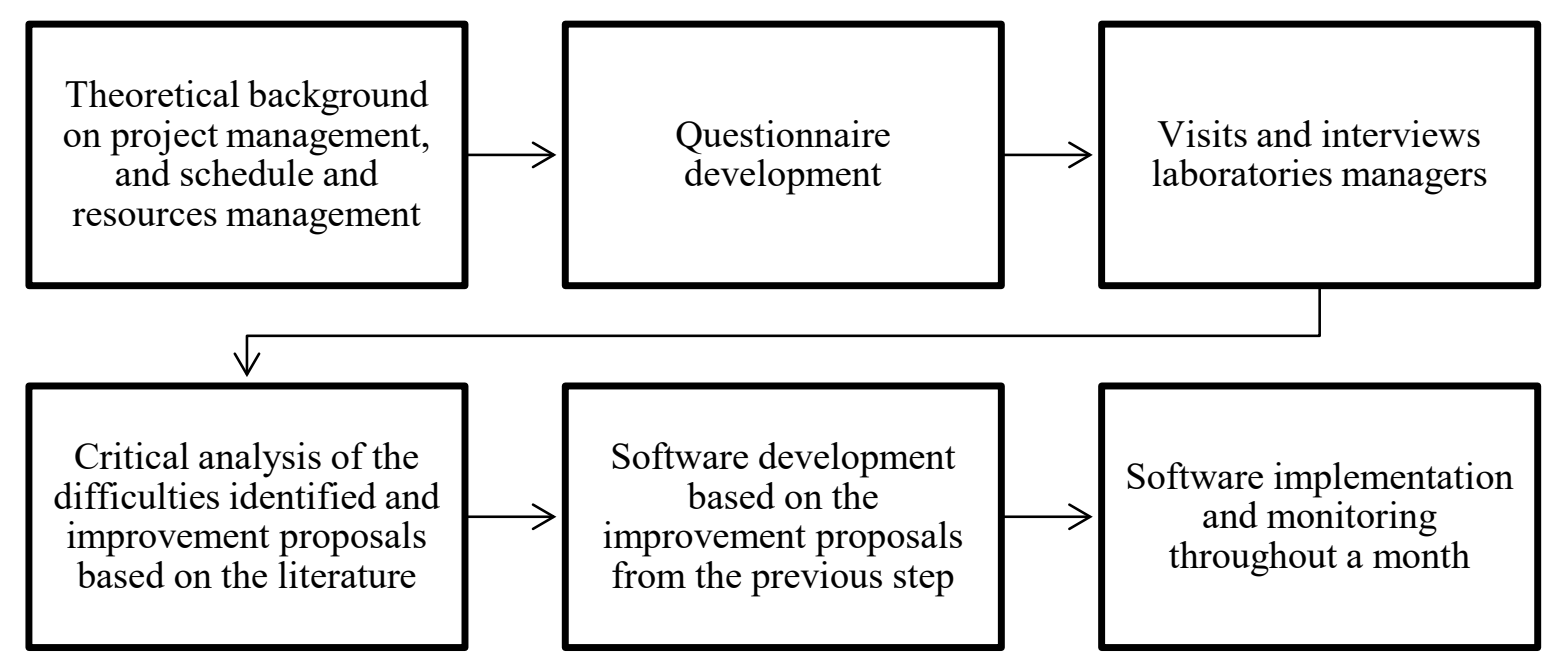

Figure 1. Steps of the research (Source: Authors)

In step 1, a literature review was conducted for theoretical foundation on the following themes: management of traditional and agile projects, schedule management, resource management and project management in research laboratories. The bibliographic survey took place with the use of the following scientific bases: Emerald, Scopus, Science Direct, Springer Link e Web of Science. The key terms used in the literature search were: "projects", "project management", "research labs", "schedule management" and "resource management", "project management methodologies" and "management guides of projects". Besides basing the critical analysis performed to develop the software, the results from this search was also used to base the theoretical background regarding the macro thematic.

In Step 2, the instrument for data collection was structured, being the same and all the study mentioned in this article approved by the University's Research Ethics Committee (CAAE: 86752618700005404). With this approval, visits, documents analysis and interviews were made with the managers of the research laboratories (Step 3). These procedures allowed a better understanding of the activities developed and the difficulties observed in the management of research projects. The research protocol used for interviews is presented in Appendix A.

Based on all the theoretical foundation and data collected in Step 3, it was possible to critically analyze the difficulties experienced and propose improvements based on the literature about traditional project management, agile projects and techniques for controlling schedules 
and resources (Step 4). It is important to highlight that the analysis of the information collected in the interviews was performed through the technique of "Content Analysis", according the guidelines of Bardin (2011). Applied to diversified discourses, it is a technique that seeks to know what is behind the meaning of words, to analyze the content to confirm the indicators that allow inferring (Santos 2012). The technique contains the following phases: a) organization of the analysis; b) coding; c) categorization; d) treatment, inference and interpretation of results. The completion of Step 4 made it possible to construct Table 1 presented in results section.

In Step 5, software was developed based on the improvements presented in Table 1 and the needs presented by the laboratory managers. The development aimed to deliver a viable minimum product, a software, that could contain the project management characteristics with theoretical framework inputs in the research laboratories segment.

Finally, in the step 6, the software implementation was done. A training was also performed in order to enable the laboratories members to use the software. The implementation was monitoring during a month to verify the results and enable a debate about them.

\section{Results and associated debates}

\subsection{Units of analysis}

The units of analysis of this case study are the LABPETRO (Experimental Petroleum Laboratory "Kelsen Valente") and the LGE (Laboratory of Flow Assurance). Both laboratories belong to the Petroleum Studies Center (CEPETRO) of School of Mechanical Engineering, in University of Campinas. As previously mentioned, due to their similarities, we considered the present research as a single case study.

LABPETRO is dedicated to diverse research on petroleum engineering, such as electric submersible pumps, friction reduction in ultraviolet oil flows, among others. LGE creates solutions for flow guarantee related problems in petroleum industry. Both laboratories have students, professors, technicians and researchers, that work simultaneously in many projects, generating scientific articles and solutions for the mentioned industry.

\subsection{Improvement opportunities identified in the laboratories' management}

The critical analysis presented in this section and the opportunities for improvement identified are derived from the data collected through a case study aided by visits and semi-structured interviews with LABPETRO and LGE laboratory managers. Both managers are experienced 
professionals with a great knowledge level about the laboratories features. Additionally, the semi-structured interviews provided opportunities for these managers to explain in detail the analyzed issues. Besides this, several visits were made to better identify and better understand specificities of the units of analysis.

A positive aspect to be mentioned is that the laboratories were already using some project management practices and tools, which facilitate improvement proposals for the multiprojects environment. According to the laboratory managers, resources and schedule management should be the focus of the improvement opportunities, since failures to comply with deadlines of activities and reports delivery impair the projects and they are a frequent issue in the laboratories. Totally, five improvement opportunities were identified from the analysis of laboratories and the analysis of the literature (specified in following subsections). These opportunities are presented in Table 1 and posteriorly detailed.

Table 1. Improvement opportunities identified in the laboratories' management. Source: Authors

\begin{tabular}{cc}
\hline N. & Improvement opportunities \\
\hline 1 & Reduced Teams and Activity \\
2 & Accumulation \\
3 & Team Seasonality \\
4 & Centralized Management \\
5 & Project deviations \\
\hline
\end{tabular}

After the identification of these improvement opportunities and an analysis of the literature about project management, it was possible to structure twenty-four possible approaches that can contribute to the better management of the studied laboratories. These were collected from six areas in the Agile and Traditional Project Management lines and will be detailed below.

\section{a) Reduced Teams and Activity Accumulation}

The first improvement opportunity refers to the reduced teams and the accumulation of activities. The need to have resources simultaneously in the multiproject environment is a reality and causes competition between activities, especially with unforeseen ones that eventually cause delays. As an example, consider taking part in bidding for new projects competing with the execution of ongoing projects, or even unforeseen activities that arise during that time. 
There are several areas that can contribute to this issue. Table 2 presents the approaches that may contribute to the problem highlighted. Multiproject Management is an area that presents manners to orchestrate activities fulfillment through scheduling priorities, queues and adjusting schedules (Beşikci et al. 2015).

Table 2. Possible actions for "Reduced Teams and Activity Accumulation". Source: vide table.

\begin{tabular}{ccc}
\hline Areas & Possible actions & References \\
\hline Multiproject & Act on scheduling, priorities and queues for & (Beşikci et al., 2015; PMI, \\
Management; & activities. & 2017a) \\
& Act on resource estimates. & (PMI, 2017a, 2017b) \\
Agile Project & Act on visibility of schedules and activities. & (PMI, 2017a, 2017b) \\
Management; & activities. & (Conforto and Amaral, 2015; \\
Schedule & Act on the visibility of the projects' situation. & (Conforto and Amaral, 2015; \\
Management. & PMI, 2017a, 2017b) \\
& Improve team sense. & (Eder, Conforto, Amaral and \\
& & Silva, 2015; PMI, 2017b) \\
\hline
\end{tabular}

In the agile management line with focus on people, the formation of self-organized teams is proposed. In general, the understanding that the result of each team member's work composes the whole is essential, as well as the understanding that individual delays can impact the whole team's results. This form of team integration enables members to focus on all activities. The sense of team can be developed in several ways, but regarding the studied laboratories, this development can be done through visibility of activities, deadlines, current status and member responsible for each activity (Conforto et al. 2014; Conforto and Amaral 2015; P.M.I. PMI 2017).

The activities visibility has other benefits. Activity accumulations by one or more members, for example, can be easily identified by the manager who will act quickly to equate and balance the workloads, generating more effective time allocation in the schedules. These propositions follow the traditional project management guidelines (Conforto 2009; Eder et al. 2015; P.M.I. PMI 2017; PMI 2017). 


\section{b) Team Seasonality}

The second plausible point of improvement is related to the team seasonality, in which students stand out. They are selected by graduate programs twice a year, in specific periods. However, the establishment of research development agreements does not have specific months to occur. Thus, the teams that are allocated in a project may have activities demands without new collaborators to execute them. This can even result in delays for projects start. In addition, project team may lose the team member (student) during project execution. Table 3 presents some possible approaches to solve this issue.

Table 3. Possible actions for "Team Seasonality”. Source: vide table.

\begin{tabular}{ccc}
\hline Areas & Possible actions & References \\
\hline Integration & Act on knowledge management. & (PMI, 2017a) \\
Management; & & \\
& Act on team development to integrate & (PMI, 2017a; Stokols et al., \\
Resource management; & new employees quickly. & 2008; Vuorinen and Martinsuo, \\
Agile Project & & \\
Management. & & \\
\hline
\end{tabular}

The enter and exit logistics of project team members is related to the team development curve, presented in the resource management of projects' traditional line (Bonebright 2010; PMI 2017). Team development should be constant and as transparent as possible. If a member leaves a project, the team must absorb the member's activities and/or knowledge to continue the project. If members join a project, they must acquire knowledge to do not disrupt the activities of other members. New members insertion should be done in a gradual, smooth and transparent manner. The integration of new contributors to the team should have their access to project documentation, reports submitted, theses, dissertations and articles written by other researchers in earlier periods. If possible, these materials should be organized to increase their autonomy and enable them to acquire the knowledge faster. These characteristics are presented in the traditional line of projects (PMI 2017).

Using the agile project management line, meetings should be periodic, for each member to expose the current situation of their activities, the activities completed, the possible impediments and problems that need solving. These meetings contribute to the integration of 
new members, especially supporting them to understand the dynamics of the laboratory and to create a sense of team (Stokols et al. 2008; PMI 2017; Vuorinen and Martinsuo 2018).

\section{c) Centralized Management}

The third opportunity for improvement refers to the centralized management presented in Table 4. Daily activity management concentrates only on the project manager all schedule assignments, upcoming activities, overdue activities, team members being charged for deadlines, developments and report deliveries. For Borges and Carvalho (2014), Toledo et al. (2008) and PMI (2017), project success requires dedication from the entire company, not just from the manager. Analyzing the literature, it is possible to observe some discussions that contribute to the problems associated with centralized management regarding human resources and equipment, as presented in Table 4.

Table 4. Possible actions for "Centralized Management". Source: vide table.

\begin{tabular}{|c|c|c|}
\hline Areas & Possible actions & References \\
\hline \multirow{3}{*}{$\begin{array}{l}\text { Agile Project } \\
\text { Management; }\end{array}$} & Act on team autonomy. & $\begin{array}{l}\text { (Conforto et al., 2016; Eder, } \\
\text { Conforto, Amaral and da } \\
\text { Silva, 2015) }\end{array}$ \\
\hline & $\begin{array}{l}\text { Act on visibility of schedules, activities and } \\
\text { responsibles for execution. }\end{array}$ & (Hoda and Murugesan, 2016) \\
\hline & Sense of team. & $\begin{array}{l}\text { (Eder, Conforto, Amaral and } \\
\text { Silva, 2015; PMI, 2017b) }\end{array}$ \\
\hline $\begin{array}{l}\text { Resource } \\
\text { management; }\end{array}$ & Regular follow-up meetings. & (Cervone, 2011; PMI, 2017b) \\
\hline \multirow{4}{*}{$\begin{array}{c}\text { Schedule } \\
\text { Management. }\end{array}$} & $\begin{array}{l}\text { Act on the visibility of equipment use allocation } \\
\text { in projects. }\end{array}$ & (Melton, 2005) \\
\hline & $\begin{array}{l}\text { Act on visibility of the critical path of the } \\
\text { projects, especially those using equipment. }\end{array}$ & (PMI, 2017a) \\
\hline & Control of projects' change. & (PMI, 2017a) \\
\hline & Visibility of projects to all team members. & (PMI, 2017a, 2017b) \\
\hline
\end{tabular}

Regarding actions for human resources, centralized management generates a perception of non-compliance with deadlines, as it is believed that part of the team is unaware of the timelines. The team expects the manager to delegate the activities and this overloads the him/her (Ahimbisibwe and Daellenbach 2016; Hoda and Murugesan 2016). Table 4 presents the possible actions for this issue. 
In the traditional and agile project management lines, the manager should act as a facilitator, as a leader, decentralizing activities and requiring results when necessary (Eder et al. 2015; Conforto et al. 2016). The periodic meetings, in agile format, contribute to the discussion, because it creates visibility and other aspects already presented. In short, meetings make it clear to the manager and team members what needs to be done for project success so that problems and impediments can be resolved quickly with the entire team support (Cervone 2011).

In actions about resources associated with equipment, the manager is responsible for equating the time of use for each activity. Equipment are robust, high technology and essential for research execution, but teams must share and use them, respecting planned deadlines. The early termination of activities, when it occurs, should be advised so that other activities can start, advancing steps. In short, the difficulties lie in how to orchestrate the use of equipment.

In the traditional line of projects, it is possible to propose the schedules management for equipment use, showing in which projects they are being used and idle periods. This can greatly facilitate the scheduling of equipment use. This approach, along with the project's critical path, gives the manager input to anticipate problems such as underuse or overuse of machines.

Another interesting approach to equipment management, inherited from the agile project line, is related to the use of a kanban board. This would allow the exposition to all team members which equipment is being used at the time. The chart would list all equipment names, team member name cards, and end-of-use date. When using an equipment, the member puts their name in the "Equipment" row and the "Responsible" column. They also puts the usage forecast based on their activity in the "End Date" column. This technique is recommended by Melton (2005).

\section{d) Project deviations}

The fourth point of improvement concerns deviations in project scope, presented in Table 5. Since projects are regarding research and innovation, it is common to have deviations for exploring unforeseen contexts initially. When this happens, managers use schedule planning to adjust them. If this is not enough, along with the other actions presented, it is necessary to deal the exceptions with risk management from the traditional line of projects. For risks, it is necessary to qualify and quantify them, create action plans and involve all stakeholders for these risks to be known. As an example, it can be mention changes requested by regulatory agencies, that must to be performed. Another example of risk beyond project control is the 
overdue in an equipment delivery. Currently, post-diversion actions are dealt with justification procedures and adjustments in deadlines and budget (PMI 2017).

Table 5. Possible actions for "Project deviations". Source: vide table.

\begin{tabular}{ccc}
\hline Areas & Possible actions & References \\
\hline & $\begin{array}{c}\text { Act on project risk planning. Quantifying } \\
\text { and Qualifying risks and Creating Action } \\
\text { Plans. }\end{array}$ & (PMI, 2017a) \\
Risk & $\begin{array}{c}\text { Regular follow-up meetings. } \\
\text { management; }\end{array}$ & $\begin{array}{c}\text { (Cervone, 2011; PMI, 2017a) } \\
\text { Agile Project }\end{array}$ \\
Management. & $\begin{array}{c}\text { Periodic deliveries with monitoring and } \\
\text { control }\end{array}$ & (PMI, 2017b) \\
& $\begin{array}{c}\text { Centralization of administrative activities. } \\
\text { Easy and centralized documentation for } \\
\text { administrative issues. }\end{array}$ & (ABGP, 2012) \\
& & (PMI, 2017a) \\
\hline
\end{tabular}

Deviations can be addressed - especially when created by the project's team - through quick deliveries over short periods. In agile project management, these periods are called Sprints, which typically last two weeks, and the team commits to delivering a Minimum Viable Product (MVP). Constant deliverables make results clear and reduce distortions. If MVP is not as planned, the suitability time is just Sprint's time, i.e. it is not too late to make corrections and the costs for corrections are minimized (P.M.I. PMI 2017).

Regarding the deviations related to the manager activities and duties, it was identified that he/she performs guidance, management and administrative support. Although administrative support does not add value to the project, it is necessary. As example of these activities, it can be mentioned the creation of equipment technical specification, according to the laws and rules; the creation of technical justifications for dismissing suppliers of bids; to quote equipment price with suppliers; and hire service providers to perform a particular activity. It is also manager responsibility to maintain dialogue with university administrative departments to resolve laboratory issues; to perform asset and inventory identification and procedures; to make adjustments related to computer network infrastructure, servers, and work environment infrastructure; among other activities that actually compete with the activities directly related to the projects. In short, it is believed that the manager's time is considerably consumed by administrative tasks rather than project management. In this sense, a proposal would be to decentralize the administrative activities, sharing them with the teams, and the 
follow-up of these activities may be followed by periodic meetings, using once again using concepts from agile and traditional lines (ABGP 2012).

Another proposal for this improvement point is the training of a laboratory member to be dedicated to administrative tasks. However, independently of the approach selected for this issue, knowledge management may be an important support, since it requires the identification, centralization and organization of documents to facilitate the increase of efficiency on this topic (PMI 2017).

\section{e) Schedule Control}

The fifth opportunity for improvement refers to the control of schedules, one of the main issues highlighted by the laboratory team. All the actions previously presented contribute to better control of the schedules, but the actions presented in Table 6 are focused on schedules.

Table 6. Possible actions for "Schedule Control". Source: vide table.

\begin{tabular}{ccc}
\hline Areas & Possible actions & References \\
\hline $\begin{array}{c}\text { Resource } \\
\text { management; }\end{array}$ & Act on visibility of the projects' critical path. & (Zancul et al., 2006) \\
& Regular follow-up meetings. & $\begin{array}{c}\text { (Cervone, 2011; PMI, } \\
\text { 2017b) }\end{array}$ \\
Schedule & Act on activity estimates. & (Hu et al., 2016) \\
Management; & Deadline predictive alerts. & (PMI, 2017a) \\
& Act on prioritizing activities. & (PMI, 2017a) \\
Agile Project & Improve estimates and plan buffers for & (Hu et al., 2016) \\
Management. & research activities, including them in & \\
& timelines. & \\
\hline
\end{tabular}

Another item to consider at this point of improvement is the predictive warnings about deadlines to the team. All team members should be aware of delivery delays before they occur. These warnings can be done in several manners, such as through a software, spreadsheets, or even periodic meetings.

Regarding the most appropriate estimation approach for project activities, particularly innovation and exploration projects, activity term estimates based on the three-point estimates (Program Evaluation and Review Technique - PERT) and consider organizational assets, if they 
exist. These can support buffers (lungs) identification and better schedule planning (Leal and De Oliveira 2011; Hu et al. 2016).

Projects' activities can be prioritized in the schedule. The traditional line of projects proposes the sequencing of activities in schedule management to subsequently identify the critical path. However, many activities can occur in parallel and are among a set of activities that can be performed. Thus, priorities identification enables the team to decide which activity should start first (Zancul et al. 2006).

\subsection{Development of a computational solution from the proposed actions}

The proposed actions can provide improvements in the management of projects developed by LABPETRO and LGE laboratories. To prove this statement, it was decided to group the referred actions in a computational solution, that is, in a software.

The development of this computational solution was based on software engineering development practices and methods. The development model used is the iterative and incremental. Iterative because there is progress through successive attempts at refinement. The software is enhanced by including details and functionality until the solution reaches a satisfactory result. It is also incremental because the solution is built and delivered by parts that comprise the whole. Thus, hypothesis exploration, customer visibility, and early deployment are allowed (Alshamrani and Bahattab 2015; Pressman and Maxim 2016). The conception of this model was composed of five steps: Communication, Planning, Modeling, Construction and Delivery, resulted from a model called waterfall (Pressman and Maxim 2019: 42), as it is shown in Figure 2. 


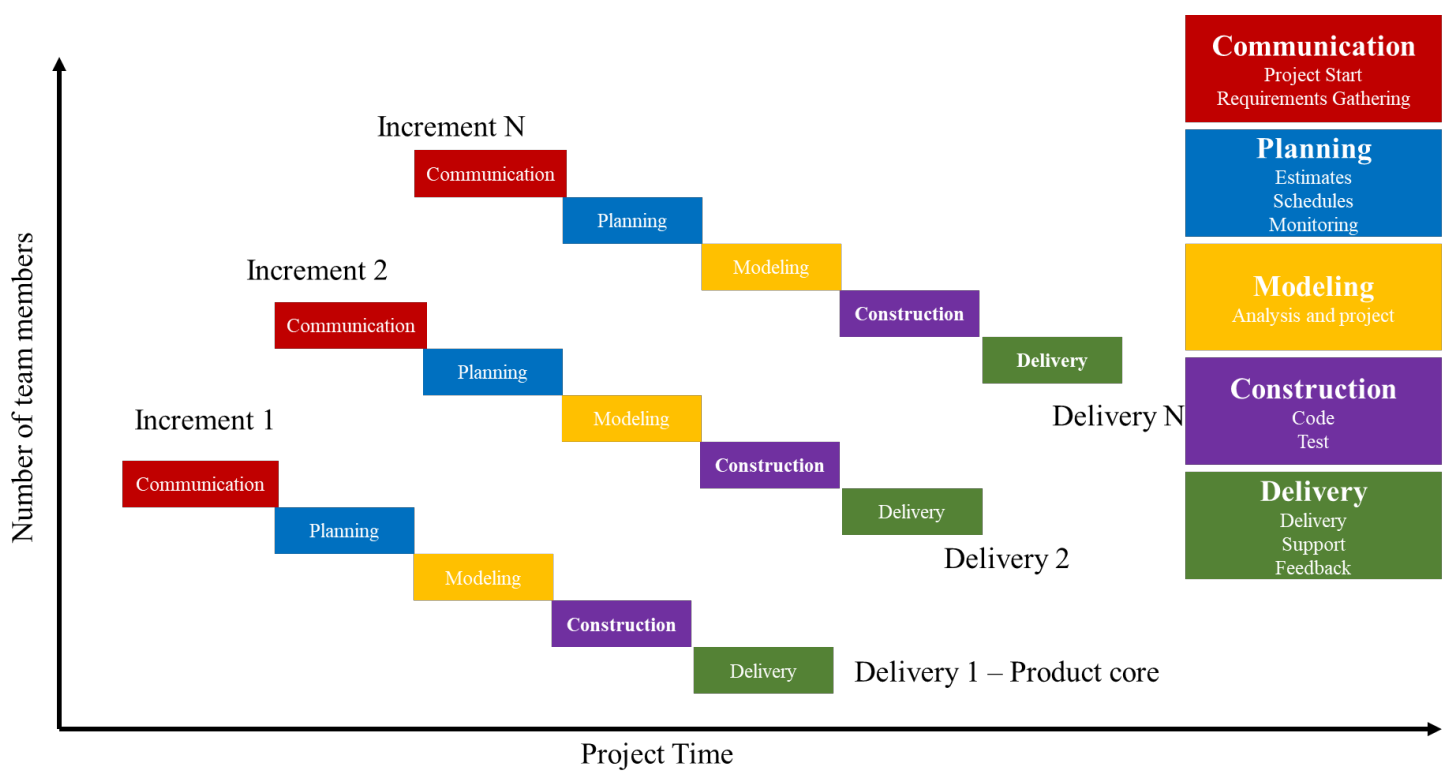

Figure 2. Interactive and Incremental Model (Adapted from (Pressman and Maxim, 2019)).

In the communication stage, meetings were done to gather software requirements. At these meetings, laboratories environment and business were explained what was expected of the software solution. This stage is based on interviews, visits and actions presented.

In the planning stage, the strategy and roadmap to achieve the tactical objectives were developed, i.e. it was established what would be the deliverables and functionalities. It is important to remember that some of the requirements are common to deal with different improvement opportunities. Thus, the requirements were grouped into nineteen items. Table 7 presents the relationship between each action and the software functionalities. The indication of an "-" indicates that there is no specific functionality to be developed in the software, but that the action necessity is met by all other functionalities. 
Table 7. Software Actions and Features. Source: Authors.

\begin{tabular}{|c|c|}
\hline Actions & Software Features \\
\hline $\begin{array}{l}\text { Act on scheduling, priorities and queues for } \\
\text { activities. }\end{array}$ & Apply priorities to activities. \\
\hline Act on resource estimates. & $\begin{array}{l}\text { Store estimated time or observed time of activities } \\
\text { and make these data visible. }\end{array}$ \\
\hline Act on visibility of schedules and activities. & $\begin{array}{l}\text { Visibility to all project members of activities and } \\
\text { deadlines. }\end{array}$ \\
\hline $\begin{array}{l}\text { Act on the visibility of resources allocated to } \\
\text { activities. }\end{array}$ & Visibility of an activity responsible. \\
\hline Act on the visibility of the projects' situation. & $\begin{array}{l}\text { Visibility of activity status and percentage of } \\
\text { completion. }\end{array}$ \\
\hline Improve team sense. & - \\
\hline Act on knowledge management. & $\begin{array}{l}\text { Store documents and other information in the } \\
\text { project. }\end{array}$ \\
\hline $\begin{array}{l}\text { Act on team development to integrate new } \\
\text { employees quickly. }\end{array}$ & $\begin{array}{l}\text { Store documents and other information in the } \\
\text { project. }\end{array}$ \\
\hline Act on team autonomy. & $\begin{array}{l}\text { Visibility of the activities and the possibility of } \\
\text { taking over the activity. }\end{array}$ \\
\hline Regular follow-up meetings. & - \\
\hline $\begin{array}{l}\text { Act on the visibility of equipment use } \\
\text { allocation in projects. }\end{array}$ & Present the projects' critical path. \\
\hline $\begin{array}{l}\text { Act on visibility of the critical path of the } \\
\text { projects, especially those using equipment. }\end{array}$ & Present the equipment used by projects. \\
\hline $\begin{array}{l}\text { Act on project risk planning. Quantifying and } \\
\text { Qualifying risks and Creating Action Plans. }\end{array}$ & $\begin{array}{l}\text { Store data of project risks and make them visible } \\
\text { to everyone. }\end{array}$ \\
\hline $\begin{array}{l}\text { Periodic deliveries with monitoring and } \\
\text { control }\end{array}$ & - \\
\hline Centralization of administrative activities. & - \\
\hline $\begin{array}{l}\text { Easy and centralized documentation for } \\
\text { administrative issues. }\end{array}$ & Store documents and other project information. \\
\hline Deadline predictive alerts. & Send emails before the activities' deadlines. \\
\hline Control of projects' change. & Registration of team members and profile. \\
\hline Visibility of projects to all team members. & Be a web application. \\
\hline
\end{tabular}

In modeling, the necessary actions are developed to represent the requirements raised at different levels of abstractions. They are divided into analysis and design models. In construction, all modeling takes shape through technical coding and tests are performed to validate the consistency of what was implemented according the requirements presented. The last activity is characterized by delivery. It is characterized by the time to present to customers 
what has been developed, the requirements implemented, how to use the software, as well as provide post-deployment support, and gather feedback for new iterations or future solutions.

The software implementation took place without major problems and it was monitored during a month, in order to identify minor adjustments and empower the users. It is worth mentioning that the use of the computational solution made it possible to improve productivity in terms of project management. This result corroborates with the literature (Cullen and Parker 2015; Larsson et al. 2018; Jugdev et al. 2019), that emphasize the role of project management for performance improvement.

\section{Conclusion and final considerations}

This article aimed to critically analyze the project management developed by the research laboratories LABPETRO and LGE of CEPETRO research center of the University of Campinas, aiming to identify opportunities for improvements in schedule and resource management. Considering the results presented, it is possible to affirm that the objective was reached.

The case study, enabled by semi-structured interviews with laboratory managers and onsite visits, allowed us to understand the activities developed and map the main difficulties observed. Five plausible points of improvement were identified: reduced teams and accumulation of activities; team seasonality; centralized management; deviations from projects; schedule control. Based on the theoretical foundation, it has been proposed actions to increase the efficiency in management of multiple research projects developed in these laboratories. As a complement, a software was structured based on the proposed actions. This software was implemented and monitored over 1 month.

The main conclusion of this study is that there is a great potential for the development of guidelines to support the management of resources and schedules in research laboratories. It has been found that the literature is a source of tools, techniques and guidelines that may support projects from different fields, including those outlined here. Research laboratories have some peculiarities in relation to the traditional conception of "projects", since they are "research projects". Despite the singularities, however, many tools and guidelines can be applied for these projects.

Solutions similar to the computational solution presented in this research can be developed, adapting the software features according to specific characteristics of each research 
laboratory. Researchers can use the findings of this application of a similar software in other research laboratories to critically analyze and compare with the present findings, enhancing the literature about this topic.

As a limitation of this research, it can be mentioned the fact that the proposal was analyzed, tested and implemented only in two laboratories of the CEPETRO Research Center of the University of Campinas. The difficulties observed in the mentioned environment and the software structuring was based on these difficulties. However, the difficulties analyzed can also be present in several other research groups. Thus, the results presented here can be of great value.

The authors thank the Artificial Lift \& Flow Assurance Research Group (ALFA) and the Center for Petroleum Studies (CEPETRO).

\section{Appendix A}

\section{Research protocol used in interviews with laboratory managers}

Question 1: What are the main activities developed by LABPETRO-FEM?

Question 2: At the moment, what are the ongoing projects?

Question 3: In general, what are the stages of a research project conducted by the laboratory?

Question 4: Currently, what are the main indicators used for research laboratory management?

Question 5: Is any management theory or method applied?

Question 6: What do you think characterizes success and what characterizes the failure of a research project?

Question 7: What are the main difficulties currently observed regarding management?

Question 8: Would the implementation of software contribute to the improvement of research laboratory management?

Question 9: If so, what features should be present in this software?

Question 10: What are the validations required for this software to meet laboratory demands?

\section{Note}

To be inserted after blind review. 


\section{References}

ABGP AB em G de P. 2012. Referencial de Competências Individuais. 1st ed. 2, editor. Rio de Janeiro: Escola Politécnica/UFRJ.

Ahimbisibwe A, Daellenbach RYC and U. 2016. A comparison of agile and traditional plan-based methodologies. J Enterp Inf Manag. 29(5):706-727.

Almeida LFM, Escola ECC, Silva SL, Amaral DC. 2012. Fatores críticos da agilidade no gerenciamento de projetos de desenvolvimento de novos produtos. Prod Produção. 13:93-113. doi:https://doi.org/10.22456/1983-8026.24824.

Alshamrani A, Bahattab A. 2015. A Comparison Between Three SDLC Models Waterfall Model , Spiral Model, and Incremental / Iterative Model. Int J Comput Sci. 12(1):106-111. doi:10.1016/j.quascirev.2007.10.001.

ANP AN de P. 2016. Biocombustíveis Regulamento Técnico - ANP - No 3/2015.

Anthony BSD, Viguerie SP, Waldeck A. 2016. Corporate Longevity: Turbulence Ahead for Large Organizations. Innosight Exec Brief.

Azanha A, Argoud ARTT, Camargo Junior JB de, Antoniolli PD. 2017. Agile project management with Scrum. Int J Manag Proj Bus. 10(1):121-142. doi:10.1108/IJMPB-06-20160054. https://www.emerald.com/insight/content/doi/10.1108/IJMPB-06-2016-0054/full/html.

Baird A, Riggins FJ. 2012. Planning and Sprinting: Use of a Hybrid Project Management Methodology within a CIS Capstone Course Aaron. J Inf Syst Educ. 3(2012):31-37. doi:10.1002/spip.

Bardin L. 2011. Análise de Conteúdo. São Paulo: EDIÇOES 70 - BRASIL.

Beck K, Beedle M, Bennekum A van, Thomas AC, Cunningham W, Fowler M, Grenning J, Highsmith J, Hunt A, Jeffries R, et al. 2001. Manifesto Ágil para Desenvolvimento de Software.

Berssaneti FT, Carvalho MM. 2015. Identification of variables that impact project success in Brazilian companies. Int J Proj Manag. 33(3):638-649. doi:10.1016/j.ijproman.2014.07.002. http://dx.doi.org/10.1016/j.ijproman.2014.07.002.

Beşikci U, Bilge Ü, Ulusoy G. 2013. Resource dedication problem in a multi-project environment. Flex Serv Manuf J. 25(1-2):206-229. doi:10.1007/s10696-012-9140-9.

Beşikci U, Bilge Ü, Ulusoy G. 2015. Multi-mode resource constrained multi-project 
scheduling and resource portfolio problem. Eur J Oper Res. 240(1):22-31. doi:10.1016/j.ejor.2014.06.025.

Boardman C, Bozeman B. 2007. Role Strain in University Research Centers. J Higher Educ. 78(4):430-463. doi:10.1353/jhe.2007.0020.

Boardman C, Gray D. 2010. The new science and engineering management: Cooperative research centers as government policies, industry strategies, and organizations. J Technol Transf. 35(5):445-459. doi:10.1007/s10961-010-9162-y.

Bonebright DA. 2010. 40 years of storming: A historical review of tuckman's model of small group development. Hum Resour Dev Int. 13(1):111-120. doi:10.1080/13678861003589099.

Borges JG, Carvalho MM de. 2014. Critérios de sucesso em projetos: um estudo exploratório considerando a interferência das variáveis tipologia de projetos e stakeholders. Production. 25(1):232-253. doi:10.1590/s0103-65132014005000019.

Cervone HF. 2011. Understanding agile project management methods using Scrum. OCLC Syst Serv Int Digit Libr Perspect. 27(1):18-22. doi:10.1108/10650751111106528.

Cicmil S, Williams T, Thomas J, Hodgson D. 2006. Rethinking Project Management: Researching the actuality of projects. Int J Proj Manag. 24(8):675-686. doi:10.1016/j.ijproman.2006.08.006.

Conforto EC. 2009. Gerenciamento ágil de projetos: proposta e avaliação de método para gestão de escopo e tempo. Universidade de São Paulo.

Conforto EC, Amaral DC. 2015. Agile project management and stage-gate model - A hybrid framework for technology-based companies. J Eng Technol Manag - JET-M. 40:1-14. doi:10.1016/j.jengtecman.2016.02.003.

Conforto EC, Amaral DC, da Silva SL, Di Felippo A, Kamikawachi DSL. 2016. The agility construct on project management theory. Int J Proj Manag. 34(4):660-674. doi:10.1016/j.ijproman.2016.01.007.

Conforto EC, Rebentisch E, Amaral DC. 2014. Project Management Agility Global Survey. Massachusetts Inst Technol Consort Eng Progr Excell -CEPE. 1:25.

Cooper Ordoñez RE. 2013. Proposta para Uso da Corrente Crítica no Gerenciamento de Múltiplos Projetos. Universidade Estadual de Campinas. 
Cullen K, Parker DW. 2015. Improving performance in project-based management: synthesizing strategic theories. Int $\mathrm{J}$ Product Perform Manag. 64(5):608-624. doi:10.1108/IJPPM-02-2014-0031. https://www.emerald.com/insight/content/doi/10.1108/IJPPM-02-2014-0031/full/html.

Cunha BCF de, Moura HP De. 2011. GMP : Uma Ferramenta para a Gestão de Múltiplos Projetos. In: II Seminário Integrado de Pesquisa. p. 8.

Dalmarco G, Zawislak PA, Hulsink W, Brambilla F. 2015. How knowledge flows in university-industry relations: An overview from two economic sectors in Brazil. Eur Bus Rev. 27(2):148-160. doi:10.1108/EBR-04-2013-0068.

Darmody PB. 2007. Henry L. Gantt and Frederick Taylor: The Pioneers of Scientific Management. AACE Int Trans.:15.1-15.3.

Davidson A, Klemme L. 2016. Why a CEO should think like a Scrum Master. Strateg Leadersh. 44(1):36-40. doi:10.1108/SL-11-2015-0086.

Eder S, Conforto EC, Amaral DC, da Silva SL. 2015. Differentiating traditional and agile project management approaches. Producao. 25(3):482-497. doi:10.1590/S010365132014005000021.

Eder S, Schnetzler JP, Luis S. 2012. Estudo das práticas de gerenciamento de projetos voltadas para desenvolvimento de produtos inovadores. Prod Produção. 13:148-165.

Edison H. 2015. Is Water-Scrum-Fall Reality? On the Use of Agile and Traditional Development Practices. Int Conf Prod Softw Process Improv. 1:607-613. doi:10.1007/978-3319-26844-6.

Etzkowitz H, Zhou C. 2017. Hélice Tríplice: inovação e empreendedorismo universidadeindústria-governo. Estud Avançados. 31(90):23-48.

Fernandez DJ, Fernandez JD. 2008. Agile Project Management —Agilism versus Traditional Approaches. J Comput Inf Syst. 49(2):10-17. doi:10.1080/08874417.2009.11646044.

Gledson BJ. 2016. Hybrid project delivery processes observed in constructor BIM innovation adoption. Constr Innov. 16(2):229-246. doi:10.1108/CI-04-2015-0020.

Grad School Hub. 2018. 50 Best Graduate Research Institutes 2018. Gradschoolhub.:151. 
Gray DO. 2008. Making Team Science Better: Applying Improvement-Oriented Evaluation Principles to Evaluation of Cooperative Research Centers. New Dir Eval.(118):7387. doi:10.1002/ev.

Habibi F, Barzinpour F, Sadjadi SJ. 2018. Resource-constrained project scheduling problem: review of past and recent developments. J Proj Manag. 3:55-88. doi:10.5267/j.jpm.2018.1.005.

Hendriks MHA, Voeten B, Kroep L. 1999. Human resource allocation in a multi-project R\&D environment: Resource capacity allocation and project portfolio planning in practice. Int J Proj Manag. 17(3):181-188. doi:10.1016/S0263-7863(98)00026-X.

Hoda R, Murugesan LK. 2016. Multi-level agile project management challenges: A selforganizing team perspective. J Syst Softw. 117:245-257. doi:10.1016/j.jss.2016.02.049.

Hoda R, Salleh N, Grundy J, Tee HM. 2017. Systematic literature reviews in agile software development: A tertiary study. Inf Softw Technol. 85:1339-1351. doi:10.1016/j.infsof.2017.01.007.

Hu X, Cui N, Demeulemeester E, Bie L. 2016. Incorporation of activity sensitivity measures into buffer management to manage project schedule risk. Eur J Oper Res. 249(2):717727. doi:10.1016/j.ejor.2015.08.066.

Ika LA. 2009. Project Success as a Topic in Project Management Journals. Proj Manag J. 40(4):6-19. doi:10.1002/pmj.20137.

Jugdev K, Mathur G, Fung T. 2019. Mediated effect of project management asset characteristics on firm performance. Int J Manag Proj Bus. doi:10.1108/IJMPB-12-2018-0284.

Kerzner H. 2016. Gestão de Projetos: As Melhores Práticas. 3th ed. New Jersey: Bookman Editora.

Larsson J, Eriksson PE, Pesämaa O. 2018. The importance of hard project management and team motivation for construction project performance. Int J Manag Proj Bus. 11(2):275288. doi:10.1108/IJMPB-04-2017-0035.

Le PB, Lei H. 2018. The effects of innovation speed and quality on differentiation and low-cost competitive advantage. Chinese Manag Stud. 12(2):305-322. doi:10.1108/CMS-102016-0195. https://www.emeraldinsight.com/doi/10.1108/CMS-10-2016-0195.

Leal LR, De Oliveira MJF. 2011. Simulação aplicada ao gerenciamento de projetos: uma 
revisão. Rev Produção Online. 11(2):503. doi:10.14488/1676-1901.v11i2.737.

Lind F, Styhre A, Aaboen L. 2013. Exploring university-industry collaboration in research centres. Eur J Innov Manag. 16(1):70-91. doi:10.1108/14601061311292869.

Marques Junior LJ, Plonski GA. 2011. Gestão de projetos em empresas no Brasil: abordagem “tamanho único”?. Gestão \& Produção. 18(1):1-12. doi:10.1590/S0104$530 \times 2011000100001$.

Mazzucchelli A, Chierici R, Abbate T, Fontana S. 2019. Exploring the microfoundations of innovation capabilities. Evidence from a cross-border R\&D partnership. Technol Forecast Soc Change. 146(May):242-252. doi:10.1016/j.techfore.2019.06.003. https://doi.org/10.1016/j.techfore.2019.06.003.

Melton T. 2005. The benefits of lean manufacturing: What lean thinking has to offer the process industries. Chem Eng Res Des. 83(6 A):662-673. doi:10.1205/cherd.04351.

Ndubisi NO, Dayan M, Yeniaras V, Al-hawari M. 2019. The effects of complementarity of knowledge and capabilities on joint innovation capabilities and service innovation: The role of competitive intensity and demand uncertainty. Ind Mark Manag.(May):1-13. doi:10.1016/j.indmarman.2019.05.011. https://doi.org/10.1016/j.indmarman.2019.05.011.

Nishimura ST, Hishinuma ES, Goebert DA, Onoye JMM, Sugimoto-matsuda JJ. 2018. A model for evaluating academic research centers: Case study of the Asian/Pacific Islander Youth Violence Prevention Center. Eval Program Plann. 66:174-182. doi:10.1016/j.evalprogplan.2017.02.010.

Ortiz-Villajos JM, Sotoca S. 2018. Innovation and business survival: A long-term approach. Res Policy. 47(8):1418-1436. doi:10.1016/j.respol.2018.04.019.

Park JG, Lee J. 2014. Knowledge sharing in information systems development projects: Explicating the role of dependence and trust. Int J Proj Manag. 32(1):153-165. doi:10.1016/j.ijproman.2013.02.004.

Patah LA, Carvalho MM de. 2016. Sucesso a partir de investimento em metodologias de gestão de projetos. Production. 26(1):129-144. doi:10.1590/0103-6513.048312.

PMI. 2017. A guide to the project management body of knowledge (PMBOK guide). 6th. 6th Editio. New York: Project Management Institute, Inc.

PMI PMI. 2017. Agile Pratice Guide. 6th ed. New York: Project Management Institute. 
Pressman R, Maxim B. 2016. Engenharia de Software: Uma Abordagem Profissional (Software Engineering: A Practitioner's Approach), 8th ed., McGraw Hill Brasil, São Paulo.

Pressman RS, Maxim BR. 2019. Software Engineering: A Practitioner's Approach. $7^{\circ}$. New York: McGraw-Hill Education.

Salehi M, Mahmoudabadi M, Adibian MS. 2018. The relationship between managerial entrenchment, earnings management and firm innovation. Int J Product Perform Manag. 67(9):2089-2107. doi:10.1108/IJPPM-03-2018-0097.

Santos FM dos. 2012. ANÁLISE DE CONTEÚdO: A VISÃO DE LAURENCE BARDIN. Rev Eletrônica Educ. 6(1):383-387.

Sarkar CB, Locatelli M. 2018. A strategic integration between Agile and traditional project management approaches for a clear view on Project Closure in the Insurance industry : The Intesa Sanpaolo Life's case study. Umeå University, Business Administration.

SCRUMstudy. 2016. Um Guia para o Conhecimento em Scrum (Guia SBOK ${ }^{\mathrm{TM}}$ ). 1st ed. SCRUMstudy, editor. Phoenix, Arizona 85008 USA: SCRUMstudy.

Serrador P, Pinto JK. 2015. Does Agile work? - A quantitative analysis of agile project success. Int J Proj Manag. 33(5):1040-1051. doi:10.1016/j.ijproman.2015.01.006.

Stokols D, Hall KL, Taylor BK, Moser RP. 2008. The Science of Team Science Overview of the Field and Introduction to the Supplement. Am J Prev Med. 35. doi:10.1016/j.amepre.2008.05.002.

Tereso A, Ribeiro P, Fernandes G, Loureiro I, Ferreira M. 2019. Project Management Practices in Private Organizations. Proj Manag J. 50(1):6-22. doi:10.1177/8756972818810966. http://journals.sagepub.com/doi/10.1177/8756972818810966.

Toledo JC de, Silva SL da, Mendes GHS, Jugend D. 2008. Fatores críticos de sucesso no gerenciamento de projetos de desenvolvimento de produto em empresas de base tecnológica de pequeno e médio porte. Gestão \& Produção. 15(1):117-134. doi:10.1590/S0104$530 X 2008000100011$.

Turner M, Scott-Young C, Holdsworth S. 2018. Developing the resilient project professional: examining the student experience. Int J Manag Proj Bus. doi:10.1108/IJMPB-012018-0001.

Vargas RV. 2016. Gerenciamento de Projetos: Estabelecendo diferenciais competitivos. 
8th ed. Rio de Janeiro: Brasport.

Vuorinen L, Martinsuo M. 2018. Program integration in multi-project change programs: agency in integration practice. Int $\mathrm{J}$ Proj Manag. 36(4):583-599. doi:10.1016/j.ijproman.2018.02.003.

Winter M, Smith C, Cooke-Davies T, Cicmil S. 2006. The importance of "process" in Rethinking Project Management: The story of a UK Government-funded research network. Int J Proj Manag. 24(8):650-662. doi:10.1016/j.ijproman.2006.08.008.

Yin RK. 2014. Case Study Research: Design and Methods. 5th ed. Thousand Oaks: SAGE Publications, Inc.

Zancul EDS, Marx R, Metzker A. 2006. Organização do trabalho no processo de desenvolvimento de produtos: a aplicação da engenharia simultânea em duas montadoras de veículos. Gestão \& Produção. 13(1):15-29. doi:10.1590/S0104-530X2006000100003.

Zhu L, Cheung SO. 2017. Harvesting Competitiveness through Building Organizational Innovation Capacity. J Manag Eng. 33(Lange 2011):1-15. doi:10.1061/(ASCE)ME.19435479.0000534.

Zika-Viktorsson A, Sundström P, Engwall M. 2006. Project overload: An exploratory study of work and management in multi-project settings. Int J Proj Manag. 24(5):385-394. doi:10.1016/j.ijproman.2006.02.010.

Zwikael O. 2016. International journal of project management special issue on "project benefit management.” Int J Proj Manag. 34(4):734-735. doi:10.1016/j.ijproman.2015.12.007. 